\title{
Creating Good Administration by Persuasion: A Case Study of the Recommendations of the Committee of Ministers of the Council of Europe ${ }^{1}$
}

\author{
Agnè Andrijauskaitè \\ German University of Administrative Sciences Speyer, Germany, Vilnius \\ University, Lithuania \\ aandrijauskaite@gmail.com
}

\section{ABSTRACT}

This contextual paper tackles a rather under-researched topic of Council of Europe's possible impact on national administrative law. It seeks to examine how one of its instruments - Recommendations of the Committee of Ministers of the Council of Europe - can influence national standards of administrative law and provide a systematic assessment of the diverse functions and manifestations such instruments might have in a national legal order. For these purposes, the constitutional basis of these recommendations and their main features are examined followed by a subsequent analysis of the perceived importance and various functions and implications they might have in the chosen national legal system. This paper concludes that the scope of the functions and implications these instruments are capable of having to national administrative law is wide, yet it is not without limitations.

Key words: Council of Europe, European administrative law, recommendations of the Committee of Ministers of the Council of Europe, pan-European principle of good administration, European Administrative Space

JEL: K39

1 This article is a revised version of the paper entitled 'Creating Good Administration by Persuasion: A Case Study of the Recommendations of the Committee of Ministers of the Council of Europe, presented at the EGPA Conference, Milano, 30 August-1 September, 2017. The EGPA contributions are not publicly available. This paper is a follow-up to FÖV Discussion Paper No. 86 'Added Value of the Council of Europe to Administrative Law: The Development of Pan-European General Principles of Good Administration by the Council of Europe and their impact on the administrative law of its Member States' written by Prof. Dr. Ulrich Stelkens and Agnè Andrijauskaitè, LL.M. It forms part of a research project entitled 'The Development of Pan-European General Principles of Good Administration by the Council of Europe and their impact on the administrative law of its Member States', which was launched at the German University of Administrative Sciences Speyer and the Research Institute for Public Administration Speyer with the financing of the German Research Foundation (Deutsche Forschungsgemeinschaft), more information available at: http:/gepris.dfg.de/gepris/ projekt/274964159. 


\section{Introduction}

Good administration seems to be in fashion and yet mostly it is analysed only in the context of the European Union (henceforth - EU). This framework is usually considered to be the 'home territory' of this concept due to a wealth of work done by the European Ombudsman in promoting it along with its inclusion into the Charter of Fundamental Rights of the EU (henceforth Charter) that eventually became legally binding. Especially since then, the discussions on good administration within the EU acquired new vigour and, among other things, led to the creation of a network of legal scholars from different EU Member States - the Research Network on EU Administrative Law (ReNEUAL) that published 'ReNEUAL Model Rules on EU Administrative Procedure' in 2014. ${ }^{2}$ Furthermore, it is oftentimes woven into the wider discourse of 'European Administrative Space'. Although no widespread understanding about its meaning exists (Trondal \& Guy Peters, 2015, p. 79), it can broadly be said to denote the coordinated implementation of EU law, as well as Europeanization of national administrative law (Hofmann, 2008, p. 662). This analytical construct was initially conceived to serve as a model for countries willing to reform their public administration and join the EU by SIGMA (Support for Improvement in Governance and Management) - a joint initiative undertaken by the Organisation for Economic Co-operation and Development (OECD) and the EU in 1992. The concept of good administration that relates to the standards and procedural requirements aiming at the protection of citizens' rights before administrative bodies as well as the judicial control of public administration formed its backbone (Koprić \& Musa \& Lalić Novak, 2011).

However, whilst focusing on the concept of good administration within the EU, the legal scholarship tends to somewhat overlook another legal framework in which this legal notion has been developed, i.e. Council of Europe's (henceforth - CoE) law. Strikingly, the existing literature on European administrative law merely (if at all) mentions the work that has been done by the CoE on this matter. ${ }^{3}$ Such a gap in existing research is surprising because not only the CoE has been actively engaged in administrative matters even since the 1970s and has managed to promulgate a "package of good administration" (Wakefield,

2 An updated English version has been published on ReNEUAL's website (http://www.reneual. eu/index.php/projects-and-publications/reneual-1-0). This version of 2015 is the basis for the English print version of the Model Rules - including linguistically improved introductions and explanations. The English print version has been published containing an additional comparative chapter ('Administrative Procedure Acts: History, Features and Reception') in 2017, see Craig \& Hofmann \& Schneider \& Ziller, 2017. More information about the work of the Research Network on EU Administrative Law (ReNEUAL) and its Model Rules on EU Administrative Procedure, can be accessed at: http://www.reneual.eu/.

3 For example, no reference to the notion of good administration developed within the CoE - not even with respect to the general principles of European Union law and the right to good administration - can be found in the following textbooks concerning European or EU Administrative Law: Chiti, 2011, Craig, 2012, von Danwitz, 2008, Harlow \& Leino \& della Cananea, 2017, Hofmann \& Rowe \& Türk, 2011, Jand \& de Lange \& Prechal \& Widdershoven, 2015, Terhechte, 2011. However, since its $2^{\text {nd }}$ edition, the textbook edited by Auby \& Dutheil de la Rochère, 2014, contains an article by U. Stelkens entitled "Vers la reconnaissance de principe généraux paneuropéens du droit administratif dans l'Europe des 47?", 713-740. A specific chapter on 'administrative law' is also missing, in Schmahl \& Brever, 2017. 
2007, p. 63) reflecting the common European heritage on the matter, but also it currently has 47 Member States, including all former Eastern bloc countries (excluding Belarus, but including Russia), ${ }^{4}$ with the population totalling more than 800 million people. Hence, its territorial scope is "truly pan-European" (Keller \& Stone Sweet, 2008, p. 5).

This limited attention given to administrative law issues stemming from the CoE might be attributed to several factors. First, the legal narrative in European administrative law is clearly shaped by the countries with long-established democratic traditions belonging to the European Union (henceforth - EU). ${ }^{5}$ Accordingly, their academic resources firstly go into exploring the field, which is closer and better (or rather more visibly) incorporated into their respective legal systems and, hence, their legal consciousness. Furthermore, EU law, with the possible exception of human rights issues, ${ }^{6}$ is perceived (although sometimes mistakenly) ${ }^{7}$ as of having a higher degree of legal bindingness and legal authority in administrative matters. ${ }^{8}$ Whereas most of the CoE legal acts, especially the recommendations of the Committee of Ministers of the $\mathrm{CoE}$, are seen as more informal, soft-law instruments, whose non-compliance entails lower costs for the Member States.

However, such a stance is not accurate because even the European Court of Human Rights (henceforth - ECtHR) in its landmark Demir and Baykara case ${ }^{9}$ made clear that it can take these recommendations (among other things) into consideration, when interpreting the norms of the European Convention for the Protection of Human Rights and Fundamental Freedoms (henceforth - ECHR, Convention). The CoE, for its part, also published the handbook "The administration and you" in 1997 wherein the principles of European administrative law were systemized including all (relevant) recommendations adopted in the field of administrative law. Furthermore, the reluctance to

4 Due to the Crimean crisis the Parliamentary Assembly of the CoE has suspended Russia's voting rights, see Resolution 1990 [2014] 10 April 2014; prolonged by Resolution 2034 [2015] 28 January 2015.

5 For example, Lithuanian law is usually compared with other legal systems of the 'usual suspects', like Germany's or France's, that are perceived to be more influential, but is less often analyzed in juxtaposition to other countries that went through transformational administrative justice reforms. However, now Lithuania is involved in transformational projects itself, like strengthening administrative capacities in Ukraine, Egypt, etc. (see more in Paužaitè-Kulvinskienè, J. The principle of effective legal protection in administrative law in Lithuania, in: Szente \& Lachmayer (Eds), 2017, pp. 190 et seq.; Paužaitè-Kulvinskienè, 2000, pp. 35-54; Ramanauskaitè, 2004, pp. 45-53).

6 As demonstrated by Article 6 (3) of the Treaty on European Union, which only recognizes European Convention for the Protection of Human Rights and Fundamental Freedoms as a part of EU law.

7 Needless to say, 'hard law' can be adopted only in those fields where the competence to the Union is given on a particular matter (Art. 5 (1) of the Treaty of the Treaty on European Union). Article 51 of the Charter provides a further limitation for the 'EU imperatives' to be passed down on the Member States in any domain.

8 This is presumably attributable to the doctrines of primacy, direct effect and direct applicability of EU law, which (although not without limitations) seem to have left an imprint on the minds of EU lawyers.

9 See Demír and Baykara v Turkey (34503/97) November 12, 2008 ECtHR (GC) at [128]. This legal interpretation technique is sometimes called 'global interpretation' (Cannizzaro, 2011, p. 522) and was also confirmed in the recent case law of the ECtHR, see Magyar Helsinki Bizottság v Hungary (18030/11) November 8, 2016 ECtHR (GC). 
deal with soft-law instruments results in missing out on the added value they can provide. Assumingly, in some respects, the recommendations of the CoE might be much more comprehensive and have wider implications to the shaping of administrative structures of the European countries. This statement rests on the premise that while EU law deals with the questions relevant for countries which already have 'a decent track record of the ruleof-law', ${ }^{10}$ the scope of the CoE law is much broader and its acts also reflect the issues of countries, which needed to create their administrative law anew.

This contextual paper seeks to examine how such recommendations might contribute to fostering the notion of good administration and provide a systematic assessment of the diverse functions and manifestations they might have. It builds up on a theoretical framework developed for the previously mentioned research project entitled 'The Development of Pan-European General Principles of Good Administration by the Council of Europe and their impact on the administrative law of its Member States' and tries to test some of its statements by making a case study of Recommendations of the Committee of Ministers of the CoE 'in action'. Thus, for the purposes of this paper, first, some general information on the constitutional basis of these recommendations and their main features will be given. ${ }^{11}$ In addition, the recommendations which are of relevance to administrative law and stand at the core of the analysis of this paper will be shortlisted. Finally, the perceived importance and various functions, manifestations and implications of such recommendations will be examined by contextualising them, i.e. by analysing their use and impact in Lithuanian administrative law to which the author of this paper is familiar. Thus, the potential of the CoE's recommendations and their possible contribution to creating good administration by persuasion ${ }^{12}$ shall be uncovered more in-depth. This in turn should attest the overall capacity of CoE's acts to influence national standards of good administration and the importance to keep the discussion on their wider impact going.

10 As evident from the rule of law being one of the pillars of the Copenhagen criteria, which any country willing to join the Union needs to meet. However, recent legal developments in some Central and Eastern European States shows that this presumption, as any other, is rebuttable.

11 More general information on the legal nature and other theoretical aspects of these recommendations, as well as on other legal sources and their interaction can be found in Stelkens \& Andrijauskaitè, 2017, pp. 34 et seq.

12 And yet it might be argued that the use of the word 'persuasion' in this context is too humble. According to Article 3 SCoE, every Member State, among other things, must collaborate sincerely and effectively in the realization of the aim of the CoE. The duty to collaborate effectively might be perceived as the duty to follow the recommendations, which are deemed to be essential for achieving the goals of the CoE by its political bodies. Article 8 SCoE, for its part, provides for the possibility of imposing sanctions on the Member States that seriously violate Article $3 \mathrm{SCoE}$. It somewhat echoes the principle of loyalty in EU law, which allows to extend the application of fundamental freedoms to matters that go beyond what is covered in the constitutional law of the EU in order to achieve the crucial goals of the EU. 


\section{The Constitutional Basis of the Recommendations of the Committee of Ministers of the CoE and their Main Features}

The constitutional foundations underpinning the CoE are laid down in its Statute (henceforth - SCoE). Among other things, Article 15 of the SCoE enshrines the instruments of the CoE essential for performing its tasks. Recommendations of the Committee of Ministers to the governments of its members are among such instruments. They have been formally adopted as 'Resolutions' until 1979 and thereafter as 'Recommendations'. ${ }^{13}$ In principle, these recommendations are not binding on the Member States. However, Member States have to report on their implementation to the Committee of Ministers. Moreover, CoE Member States might even formally express reservations with regard to recommendations, i.e. to employ an instrument that has been derived from international treaty law (Brever, 2017, p. 807). Therefore, despite their non-binding character, recommendations are not entirely irrelevant to the Member States, especially because Article 15 (b) SCoE explicitly confers on the Committee of Ministers the right to request that the Governments of Member States inform it of the action taken by them with regard to such recommendations.

The recommendations vary in scope, but tend to have the same structure: a concise text of the resolution is usually followed by an annex, which, for its part, is explained by an explanatory memorandum. ${ }^{14}$ By means of a resolution, Member States are encouraged to take necessary measures in order to align their domestic law with the standards enshrined therein. Laying such standards down in an annex is supposed to facilitate this task for the Member States. Sometimes annexes of these recommendations are also accompanied by a preamble, which specifies their scope of application. Unfortunately, these recommendations have never been collected in a sort of 'Official Journal' of the CoE, instead circulating for years often only as (bad) copies of typewritten originals. Today, however, all recommendations and resolutions of the Committee of Ministers (typically) including the preparatory documents and explanatory memorandums can be found on its website. ${ }^{15}$ These recommendations differ from the "conclusions in the form

13 For a detailed discussion on recommendations see Alincai, 2012, pp. 84-103; Bartsch, H.J. The Acceptance of Recommendations and Conventions within the Council of Europe, in: Le rôle de la volonté dans les actes juridiques - études à la mémoire du professeur Alfred Rieg, 2000, pp. 91-99; Jung, H. Die Empfehlungen des Ministerkomitees des Europarates - zugleich ein Beitrag zur europäischen Rechtsquellenlehre, in: Bröhmer et al. (Eds), 2005, pp. 519-526; Palmieri, 2006, pp. 51-84; Polakiewicz, J. Alternatives to Treaty-Making and Law-Making by Treaty and Expert Bodies in the Council of Europe, in: Wolfrum \& Röben (Eds.), 2005, pp. 245-290; Polakiewicz, 2012, pp. 167-195; Uerpmann-Wittzack, R. Rechtsfortbildung durch Europaratsrecht, in: Brever et al. (Eds) (2013), pp. 939-951; De Vel, G. \& Markert, T. Importance and Weaknesses of the Council of Europe Conventions and of the Recommendations addressed by the Committee of Ministers to Member States, in: Haller et al. (Eds), 2000, pp. 345-353; Wittinger, 2005, pp. 202 et seq.

14 The explanatory memorandums of the recommendations can (often) be found as 'related' documents together with the recommendations on the website of the Committee of Ministers: http://www.coe.int/en/web/cm/documents. Those of the older recommendations on administrative law can also be found in Council of Europe (Ed.), 1997.

15 http://www.coe.int/en/web/cm/documents. 
of recommendations, to the Committee of Ministers" of the Parliamentary Assembly of the CoE, which are foreseen in Article 22 of the SCoE.

As noted above, the CoE has been actively engaged in administrative matters since the 1970s. One of the first milestones in its work, was the adoption of Resolution (77) 31 on the protection of the individual in relation to acts of administrative authorities, ${ }^{16}$ which had been prepared by the Project Group on Administrative Law (henceforth - CJ-DA) and set out the basis for further cooperation among the Member States in the field of administrative matters. Its preamble echoed the idea that recommendations are capable of expressing the broad consensus on a concrete matter: "in spite of the differences [...] there is a broad consensus concerning the fundamental principles which should guide the administrative procedures [...]". Thus, Resolution (77) 31 codified five of these principles: the right to be heard, access to information, assistance and representation, statement of reasons, and indication of remedies. These and further principles that are considered to be of primary importance for the protection of the individual against the administration are detailed in a manual published in 1997 by the CoE (Council of Europe (Ed.), 1997), intended to be of use to legislators, judges, ombudsmen, administrators, lawyers, and interested members of the public in all European States.

Since then, an array of other recommendations have been prepared by the CJ-DA and adopted by the Committee of Ministers. For the purposes of this paper, the following further recommendations are worthy of special attention:

- Recommendation No. R (80) 2 concerning the exercise of discretionary powers by administrative authorities;

- Recommendation No. R (81) 19 on access to information held by public authorities, which has been revised (but not replaced) by Recommendation $\operatorname{Rec}(2002) 2$ on access to official documents;

- Recommendation No. R (84) 15 relating to public liability;

- Recommendation No R (85) 13 on the institution of the ombudsman;

- Recommendation No. R (87) 16 on administrative procedures affecting a large number of persons;

- Recommendation No. R (89) 8 on provisional court protection in administrative matters;

- Recommendation No. R (91) 10 on the communication to third parties of personal data held by public bodies;

- Recommendation No. R (91) 1 on administrative sanctions;

- Recommendation No. R (93) 7 on privatisation of public undertakings and activities;

- Recommendation No. R (97) 7 on local public services and the rights of their users;

16 For more details see Berchtold, K. Über die Rechtsharmonisierung des Verwaltungsrechts im Europarat, in: Hummer \& Wagner (Eds.), 1988, pp. 404 et seq.; Classen, 2008, pp. 206 et seq. 
- Recommendation No. R (2000) 6 on the status of public officials in Europe;

- Recommendation No. R (2000) 10 on codes of conduct for public officials;

- Recommendation Rec(2001) 9 on alternatives to litigation between administrative authorities and private parties;

- Recommendation Rec(2003) 16 on the execution of administrative and judicial decisions in the field of administrative law;

- Recommendation Rec(2004) 20 on judicial review of administrative acts;

- Recommendation CM/Rec(2007)7 on good administration.

\section{The Perceived Importance of Recommendations of the Committee of Ministers of the CoE in Lithuanian Administrative Law}

Before going into the concrete functions and implications the recommendations of the Committee of Ministers of the CoE may have, it is worthwhile to have a closer look on their general importance as perceived by the national legal actors. An analysis conducted with the aim of finding out such general attitude towards these recommendations, ${ }^{17}$ has revealed that the previously shortlisted recommendations in Lithuanian administrative law can inspire (tangible) legislative changes, as well as are held in high regard by administrative courts. Travaux préparatoires on both the Law on Public Administration (Viešojo administravimo jstatymas) and Law on the Proceedings of Administrative Cases (Administraciniu bylu teisenos istatymas) explicitly mention and discuss CoE recommendations, where they are relevant, including when a need arises to update legislation already in place. ${ }^{18}$ Apart from these (partially) codified sources of Lithuanian administrative law, CoE's recommendations can inspire building the legal framework in more specific areas of administrative law, such as state liability. ${ }^{19}$

Administrative courts, for their part, see Recommendations of the Committee of Ministers of the CoE as important sources of legal reasoning:

"<...> general principles enshrined in recommendations reflect the experience of democratic European states, as well as the results of the

17 Namely, a search in the case-law of administrative courts of Lithuania, as well as in the Register of Legal Acts (www.e-tar.lt) for the purposes of this article was performed by using the relevant keywords, such as the titles of the previously shortlisted Recommendations.

18 Such as the need to update legislation on interim measures in administrative procedure. See part 4.4 of this paper.

19 Above all, Recommendation No. R (84) 15 relating to public liability was taken into consideration whilst preparing Article 6.271 of the Civil Code of the Republic of Lithuania, which regulates liability to compensation for damage caused by unlawful actions of institutions of public authority (available in English at: https://e-seimas.lrs.lt/portal/legalAct/ It/TAD/TAIS.245495). Even though legal provisions governing state liability are laid down in the Civil Code, administrative courts are entrusted with hearing cases on such matters in Lithuania. 
Council of Europe's work in the field of administrative law. They constitute an important source of interpretation of legal norms $<\ldots>$.. ${ }^{20}$

In addition, the Recommendations of the Committee of Ministers of the CoE are regarded as the sources of law and legal reasoning, which are contemporary:

"<... the usefulness of other methods of control of administrative acts for improving the functioning of jurisdictions and for the effective protection of everyone's rights is declared in the Recommendation Rec(2004)20 of the Committee of Ministers to Member States on Judicial Review of Administrative Acts. This recommendation prescribes that natural and legal persons may be required to exhaust remedies provided by national law before having recourse to judicial review. Thus, it is obvious that the introduction of the requirement to makeuse of theout-of-courtinvestigation of administrative disputes (in some cases being even compulsory), reflects the aspirations of contemporary administrative justice: the priority of protecting individual rights vis-à-vis a State's interests and effective legal protection of those rights $<\ldots .>{ }^{\prime \prime}{ }^{21}$

The fact that the Recommendations of the Committee of Ministers of the CoE are given high legal authority is further attested by the fact that in none of the cases analysed their legal power was called into question. Administrative courts seem not to be getting involved into discussions, whether such recommendations are legally binding and simply apply them for various purposes where relevant (see the section below). The possible limitations stemming from their soft-law nature appear not to cause any concern for the litigants either, who proactively refer to relevant legal provisions of the recommendations in their pleadings. This is an understandable position to take bearing in mind that, as demonstrated below, recommendations in the analysed case law were mostly used either in order to support a statement by a court or to develop a conceptual framework meant to support a statement (von Bogdandy, 2017, p. 21). In none of the cases were they used to quash national provisions altogether, where the questioning of their legal nature might be relevant in order to sustain legal certainty.

\section{The Added Value of the Recommendations of the Committee of Ministers of the CoE}

After having briefly analysed the general importance of Recommendations of the Committee of Ministers of the CoE as perceived by Lithuanian lawgiver and the judiciary, we should turn to a variety of functions they perform when 'put into action' by the same legal actors. This can help to unlock the exact effects and the overall potential CoE's instruments may have to offer to

20 Supreme Administrative Court of Lithuania, Decision of 30 September, 2005 - Case No. A-05665-05.

21 Supreme Administrative Court of Lithuania, Decision of 8 June, 2012 - Case No. A A $^{520}$ $2320 / 2012$. 
administrative law, especially in cases where relevant national instruments are missing or (for some reason) seem to be inefficient.

\subsection{Recommendations as Legal Sources used for Legitimising (especially for 'progressive' or 'controversial' judgments)}

The first function that the Recommendations of the Committee of Ministers of the CoE can serve to national administrative law is that of giving more legal authority to the decisions or judgments by administrative courts that might be seen as too 'progressive' or 'controversial' by the public. Attributing (at least partially) legal arguments for 'controversial' decisions to somewhat distant, supranational bodies primarily preoccupied with interpreting fundamental rights in a dynamic and progressive way, taking into account of recent developments in society (Gerards, J. Judicial Deliberations in the European Court of Human Rights, in: Huls, \& Adams \& Bomhoff (Eds), 2008, pp. 407-436), makes such judgments seem more legitimate and, thus, more acceptable to the public at large. The more 'controversial' such a judgment is, the more sources of legal argumentation are usually used all at once in order to legitimise it in the eyes of the public, even though (pragmatically seen) the principles stemming exclusively from the (national) Constitution or other 'conventional' sources of national law suffice.

This approach was used in a case concerning the legality of a permit to organise Baltic Pride 2010 - an annual LGBT pride parade rotating in turn between the capitals of the Baltic States - granted by Vilnius city municipality administration. ${ }^{22}$ In this case, one politician and the Attorney General of Lithuania have asked an administrative court to grant provisional protection - to stay an administrative decision allowing the parade. Such claim was made several days before Battic Pride was scheduled to take place and it was evident that the application of interim measures (if deemed necessary by an administrative court) would prevent it from happening. The applicants brought forward "the possibility of endangering the public safety" and "undermining traditional values supported by the public at large" as main arguments in support of their claim.

Supreme Administrative Court of Lithuania (henceforth - the Court) did not rule in support of such arguments and dismissed the application for interim relief. For justifying its decision, the Court, among other things, relied on the Recommendations of the Committee of Ministers of the CoE in (quite) a condensed manner: firstly, the Recommendation No. R (89) 8 on provisional court protection in administrative matters and the Recommendation $\operatorname{Rec}(2003) 16$ on the execution of administrative and judicial decisions in the field of administrative law were used to explicate the nature and purpose of interim relief in administrative proceedings. Then, together with Article 11 of the Convention, which grants the right to free assembly and relevant case-law ${ }^{23}$ of the ECtHR on this Article, more 'topical' Recommendation was

22 See Supreme Administrative Court of Lithuania, Decision of 7 May, 2010 - Case No. AS 822 $339 / 2010$.

23 See Bączkowski and Others v Poland (1543/06) May 3, 2007 ECtHR. 
used, namely - Recommendation CM/Rec(2010)5 on measures to combat discrimination on grounds of sexual orientation or gender identity. Whilst weighing up various conflicting interests at stake, the Court took into consideration relevant provisions of this Recommendation (§ 14, 15 and 16 of its Annex). Especially, the provision recommending Member States to take appropriate measures to prevent restrictions on the effective enjoyment of the rights to freedom of expression and peaceful assembly resulting from the abuse of legal or administrative provisions, for example on grounds of public health, public morality and public order (which was exactly the case in the current proceedings) has played a role in the Court's argumentation. Drawing on these provisions, the Court declared that granting interim measures in this case would be disproportionate and the balance between competing interests would not be maintained.

Besides exemplifying how reliance on provisions stemming from the CoE can legitimise ${ }^{24}$ upholding of 'controversial' decisions and make them look less arbitrary, the said case demonstrates that (just like the ECtHR in the previously mentioned Demir and Baykara formula) the national courts are prone to make use of the provisions of Recommendations of the CoE for interpreting Convention's rights and concretizing their normative content. In the said case, Article 11 of the Convention was explicated with the help of legal provisions of relevant Recommendations of the Committee of Ministers of the CoE and interpreted in a way that allowed the Court to reach a 'Convention-friendly' decision.

The same 'Demir and Baykara' approach was used in cases regarding public liability claims. At first glance the use of CoE's recommendations, namely Recommendation No. R (84) 15 relating to public liability - seems superfluous in such cases because public liability is quite comprehensively regulated in the Civil Code of Lithuania. However, a closer look reveals that, as already mentioned, exactly this recommendation gave impetus to the adoption of national rules on public liability claims and, thus, according to the Court, shall be "taken into consideration in order to better understand the provisions of the Civil Code on this matter". ${ }^{25}$ This is, hence, a telling example as of how supranational law can serve a double function: first, influence the adoption of national rules and, secondly, be used for elucidating their content.

\subsection{Recommendations as Tools to Explain Vague or Non-Existing Legal Notions}

Apart from helping the judiciary to pass judgments on controversial topics by diversifying available legal sources and thus making it more legitimate for the public at large, the Recommendations of the Committee of Ministers of the

24 Needless to say, legitimising function does not work for public members holding radical (populist) beliefs. For them, such decisions are another piece of evidence that proves the perceived existence of the 'Dictate of Brussels' - a term used to denote the loss of national sovereignty and supranational legislation being 'the mother of all evils'.

25 See, e.g., Supreme Administrative Court of Lithuania, Decision of 23 March, 2013 - Case No. A-642-858/2015. 
CoE can also contribute to the introduction of 'new' or help to explain vague legal notions to a particular legal community. This, in turn, helps to broaden 'epistemic horizons' of the judiciary and solve administrative disputes in a more conceptual way.

The clearest example thereof is a case in which the notion of suspensive effect of administrative act enshrined in the CoE instruments was introduced to Lithuanian legal system. It was firstly done in the case which - yet again involved the question of applying provisional protection. ${ }^{26}$ The Court was asked to issue an interim order - a suspension of the execution of administrative fine imposed on an applicant for infringing competition law. The Law on Competition of the Republic of Lithuania, among other things, provided that the filing of an appeal does not stop an execution of administrative acts adopted as a result for the violation of this Law, provided that the court has not decided differently. The Court compared this national rule to the provisions found in the Recommendation No. R (89) 8 on provisional court protection in administrative matters and in its Explanatory Memorandum: according to this Recommendation, an administrative act is as a rule immediately enforceable, except for the cases where the law grants suspensive effect to such acts until a particular administrative dispute is resolved by the court. The Court concluded that the national legal framework at hand was compatible with the regulation set forth in the CoE's law and used the notion of suspensive effect (clearly articulated in the Recommendation No. R (89) 8) to build up its further legal argumentation: the suspensive effect [an administrative act is capable of having] must be explicitly foreseen in the law; if that is not the case, then the general rule applies and an appeal of an administrative act to an administrative court is not a valid reason per se to withhold its execution. Thus, the decisive point for the Court in this dispute was [to check] whether there are enough factual circumstances justifying the granting of provisional protection and, thus, deviation from the general rule that an appeal to a court does not entail suspensive effect on the execution of an administrative act.

This case is a clear example of how this (quite theoretical) notion infused into national law through CoE's instruments and helped to solve an administrative dispute in a more conceptual way. It seems that this notion was previously relatively unknown or at least not well articulated in Lithuanian administrative law, however, it managed to take root ever since ${ }^{27}$ as attested by subsequent cases elaborating on the notion of suspensive effect an administrative act is capable of having further. ${ }^{28} \mathrm{As}$ in the previous example, the Recommendations of the Committee of Ministers of the CoE once again found use in a case which

26 See Supreme Administrative Court of Lithuania, Decision of 21 February, 2013 - Case No. $\mathrm{AS}^{602}-223 / 2013$.

27 Lithuanian law in general seems to be quite receptive of legal notions that are not necessarily codified. A telling example thereof is the case of the protection of legitimate expectations. Lithuanian courts 'embraced' this (at least for the major European legal systems) classical doctrine as its own without any scholarly discussions, when the Constitutional Court derived it from the constitutional principle of the rule of law in 2001 (See more in Piličiauskas \& Andrijauskaitè, 2014, p. 326).

28 See, e.g., Supreme Administrative Court of Lithuania, Decision of 3 September, 2014 - Case No. AS $261-670 / 2014$, Decision of 22 October, 2014 - Case No. AS261-1048/2014. 
had significant wider public interest. Namely because huge administrative fines were imposed on three biggest banks operating in Lithuania for their anticompetitive behaviour in the analysed case. ${ }^{29}$ Assumingly, as well as in the previously described 'Baltic Pride case' - the judges in this case also felt additional pressure to make legal argumentation more comprehensive and turned to supranational legal acts in order to solve a particular case conceptually rather than ad hoc.

\subsection{Recommendations as Legal Sources Helping to Solve a Dispute faute de mieux}

Another function Recommendations of the Committee of Ministers of the CoE are capable of performing is the so-called faute de mieux function, i.e. when the application of supranational legal provisions in a legal dispute occurs whilst lacking a better alternative. Such function seems to find its use when domestic legal provisions leave a wide margin of appreciation for the court and/or the administration or, especially, when there are no legal provisions on a particular matter. The court, for its part, cannot refuse to solve a dispute due to the dearth of applicable legal norms. Otherwise, the denial of justice would be inevitable, which is incompatible with the very essence of the rule of law. In many countries, the Constitution and the rule of law imperative and the principles and rights derived therefrom, thus, serve as the solution to this problem. ${ }^{30}$ However, deriving various rights and principles from the national legal sources is based on nothing more than assumption that a particular right or principle in fact exists there.

The argument for using faute de mieuxapproach in order to solve administrative disputes can be deduced from Article 4 (7) of the Law on the Proceedings of Administrative Cases of Lithuania, which states that in the silence of law a court should solve a dispute at hand by using legal analogy (i.e. provisions that regulate similar legal relations) or be guided by "fundamentals and the meaning of laws, as well as the principles of equity and reasonableness". Especially, the latter open-ended clause can be seen as justifying the use of faute de mieux approach. The case law has also added that "in vacatio legis situations, courts shall take into consideration "implicit [legal regulation], which is a corollary to explicit legal provisions". ${ }^{31}$ Bearing that in mind, it can be stated that the pan-European rules set forth in CoE's Recommendations, which codify minimal common standards European nation agree upon in

29 More information available at: https://kt.gov.lt/en/news/lithuanian-competition-councilimposes-fines-on-security-services-provider-and-three-banks-for-restricting-competition-incash-handling-and-cash-in-transit-services-2.

30 This is, e.g., the case in Germany (Stelkens, 2004, pp. 151 et seq.), as well as in Lithuania. An idea that 'the constitutional principle of a state under the rule of law is especially capacious; it comprises a range of various interrelated imperatives' formulated by the Constitutional Court of Lithuania - is oftentimes used as a sort of 'methodological justification' for deriving various legal requirements explicitly not found in the law applicable to a particular conflict.

31 See Supreme Administrative Court of Lithuania, Decision of 27 February, 2017 - Case No. eA2413-662/2017; Decision of 28 February, 2017 - Case No. A-2445-624/2017; Decision of 8 March, 2017 - Case No. A-2823-492/2017; Decision of 19 April, 2017 - Case No. eA-3294$624 / 2017$. 
administrative matters, can be employed to disclose that missing, and yet required normative content in order to solve an administrative dispute.

Such faute de mieux notion was employed in a case in which the Court was faced with the question of whether domestic migration authorities had acted lawfully in withdrawing subsidiary protection given to an asylum seeker without providing him with a possibility to be heard..$^{32}$ The right to be heard in a procedure for subsidiary protection was not enshrined in national law. Thus, the Court had to turn to general principles and supranational sources of law in order to resolve the case. Together with deriving the right to be heard before withdrawing subsidiary protection from domestic constitutional law (namely Article 5 (3) of the Lithuanian Constitution providing that "State institutions shall serve the people") and the Charter, the court singled out and made use of the Recommendation CM/Rec(2007)7 on good administration as a relevant source of legal knowledge. Namely, the Court, among other things, drew its attention to Article 14 of the Recommendation CM/Rec(2007)7, which stipulates that an opportunity to express views must be given to private persons before issuing any measure which may adversely affect their rights. Hence, the national migration authorities were also obliged to furnish an asylum seeker at issue with a possibility to be heard before withdrawing subsidiary protection regardless of the fact that the national law did not explicitly grant such right.

Another telling example of using faute de mieux approach can be found in a case in which the Court had to decide whether the Insurance Commission (the regulator of Lithuania's insurance companies) had the right to publish information on imposing administrative sanctions on the contravening insurance companies on its website. In other words, the Insurance Commission was putting individual administrative acts (by which companies found to be infringing laws governing insurance were penalized) online. In order to resolve this dispute, the Court directly relied on the first principle of the Recommendation No. R (91) 1 on administrative sanctions, which states that "the applicable administrative sanctions and the circumstances in which they may be imposed shall be laid down by law". Taking into consideration that neither Lithuanian Law on Insurance, nor other relevant domestic laws had furnished the Insurance Commission with a right to make decisions on administrative sanctions against contravening insurers public, the Court compared such practise to "the introduction of quasi administrative sanctions" and, hence, unlawful. ${ }^{33}$

The latter legal case demonstrates how a single provision can help to solve an entire administrative dispute in a real faute de mieux situation - where national norms, as well as even EU law, which is oftentimes used as a 'lifebuoy'

32 See Supreme Administrative Court of Lithuania, Decision of 8 December, 2010 - Case No. A756-686/2010. Short presentation of the case in English available at: http://fra.europa.eu/en/ caselaw-reference/lithuania-supreme-administrative-court-lithuania-case-no-a756-6862010.

33 See Supreme Administrative Court of Lithuania - Decision of 27 September, 2005 - Case No. $A^{15}-626 / 2005$. 
in similar situations, despite its (sometimes) formal lack of bindingness on a particular dispute, are silent.

\subsection{Recommendations as Driving Forces for Change}

An array of Recommendations of the Committee of Ministers of the CoE can also catalyze changes in the national legal framework, i.e. they can have a transformational effect. In Lithuania, a 'silent revolution' seems to have happened in regard to the regulation on provisional protection in administrative procedural law, whose causes can be traced back to the discrepancy between national provisions and the regulation enshrined in Recommendation No. R (89) 8 on provisional court protection in administrative matters.

Previously, the case-law on the subject was quite unequivocal and strictly followed the letter of the [national] law: an administrative court could only grant provisional protection if "[not granting such protection] would make the execution of the final decision of the court impossible or hardly possible, i.e. the restoration of the status quo ante would become impossible or hardly possible". ${ }^{34}$ Whereas the consideration of prima facie arguments against the validity of administrative act was clearly rejected in the case-law, ${ }^{35}$ even though administrative courts were perfectly aware that it is prescribed by the Principle II of Recommendation No. R (89) 8 and even quoted this provision in their decisions without following it.

This trend started to change since the year 2013, when administrative courts began to rely on the said provision of Recommendation No. R (89) and actually examine whether there are prima facie arguments against the validity of contested administrative act that also militate in favour of granting provisional protection. However, these prima facie arguments were always examined among other things, i.e. together with other applicable criteria de lege lata. No obvious motivation why such a change took place can be extracted from the case-law, but notably it originated in a series of legal cases, which were examined by the same reporting judge. ${ }^{36}$ Assumingly, such inclination to resolve the questions on applying interim measures in the spirit of Recommendation No. R (89) somewhat influenced other judges to follow the lead set by that reporting judge. ${ }^{37}$ Finally, this judicial volte-face morphed into legislative changes, i.e. into an amendment to the relevant provision of Lithuanian Law on the Proceedings of Administrative Cases, which currently seems to replicate the wording of Principle II of Recommendation No. R (89) 8: “< ..> provisional protection can be granted, if not doing so would cause

34 Articles of 71 (1) and 92 of Lithuanian Law on the Proceedings of Administrative Cases (wording of the Law applicable until $1^{\text {st }}$ of July, 2016).

35 See Supreme Administrative Court of Lithuania - Decision of 20 September, 2010 - Case No. AS ${ }^{858}-602 / 2010 ;$ Decision of 24 September, 2010 - Case No. AS ${ }^{858}-620 / 2010$; Decision of 29 October, 2010 - Case No. AS ${ }^{858}-670 / 2010 ;$ Decision of 15 April, 2011 - Case No. AS ${ }^{146}$ 297/2011 and others.

36 See Supreme Administrative Court of Lithuania - Decision of 26 February, 2014 - Case No. $\mathrm{AS}^{602}-161 / 2014$; Decision of 20 August, 2014 - AS S02 $_{-573 / 2014}$; Decision of 23 September, 2014 - Case No. AS $602-965 / 2014$.

37 See Supreme Administrative Court of Lithuania - Decision of 3 September, 2014 - Case No. AS $^{261}$-670/2014; Decision of 22 October, 2014 - Case No. AS $261-1048 / 2014$. 
severe damage which could not be made good or could only be made good with difficulty and if there is a prima facie case against the validity of the act". ${ }^{38}$ Thus, instead of linking the granting of court's provisional protection to "the execution of the final decision of the court [made] impossible or hardly possible" as previously, the national legislator introduced "irreparable harm and prima facie arguments against the validity of administrative act" as decisive criteria for issuing interim measures. Finally, an assumption that influence stemming from the CoE has caused a 'silent [procedural] revolution' is further attested by the travaux préparatoires on the amendments of this provision. They, for their part, explicitly mention the need to bring Lithuanian administrative procedural law in line with Recommendation No. R (89) as one of the reasons for such a change in the legal framework.

However, this example also shows that while administrative courts аге susceptible to CoE's regulation whilst solving 'controversial' or other substantive questions of administrative law, they are much more reserved when it comes to procedural law. In procedural law, the Lithuanian judiciary tends to 'play it safe' and stick to the letter of the national law. The precise wordings of relevant procedural provisions can thus be 'straitjackets', which prevent innovative concepts from flowing into the national law effectively. This tendency might be explicated by deep-seated perception of administrative procedure being of formal nature and remaining within the bounds of national law. ${ }^{39}$

\section{Conclusion}

This contextual paper has sought to delve into the relatively under-researched area of European administrative law, i.e. CoE's work in administrative matters and its impact on the national legal systems of its Member States, by making a case study of the use and various functions of Recommendations of the Committee of Ministers of the CoE in the chosen national order. The conducted analysis thereof has revealed that in this chosen legal order Lithuanian national law - the said instruments of the CoE can not only inspire the adoption or changes of national legal provisions, but are also held in high regard by the judiciary. For administrative courts, the CoE's recommendations can be an important source of legal knowledge capable of reflecting the aspirations of contemporary administrative justice. Their 'soft-law nature' is not perceived as an obstacle to this end. Apart from this general importance of the recommendations recognized by national legal actors, a case study showed that Recommendations of the Committee of Ministers of the CoE are also capable of serving such (more specific) functions: (i) to give more legal authority to decisions or judgments, especially when an administrative dispute is perceived as 'controversial' or of high interest by the public; (ii) to help interpret, concretize and understand various Convention norms better, thus allowing the national judiciary not to fall into contradiction with the

38 Article 70 (1) of Lithuanian Law on the Proceedings of Administrative Cases (wording of the Law applicable from $1^{\text {st }}$ of July, 2016).

39 In a similar way as Member States cling to their national procedural autonomy in EU Law. 
duties enshrined therein; (iii) to introduce 'new' or help to understand vague legal notions and be instrumental for administrative courts, which are willing to solve administrative disputes in a more conceptual way; (iv) to solve an administrative dispute faute de mieux, where national norms on a particular matter are non-existent; (v) to push for reforms where the national legislation is outdated or normatively limited.

It transpired that the scope of functions and implications the Recommendations of the Committee of Ministers of the CoE can have to national administrative law is wide, yet not without limitations. Whereas in 'controversial' administrative matters they are seen as adding up 'legal weight' to solving a particular dispute and thus are easily relied on, in certain domains, like administrative procedural law, their acceptance appears to be protracted. Thus, it can be said that the good administration by persuasion, i.e. triggered by soft-law instruments of the CoE, is feasible, but only to the extent national legal actors are willing to make it happen. It also goes without saying, that the effects these recommendations can bring are in no way exhaustive and remain to be uncovered by further research. Among other things, a comparative research examining how Recommendations of the Committee of Ministers of the CoE permeate 'younger' and 'older' European legal systems and whether there are any major differences in reception of these acts between them would be worthwhile.

Agne Andrijauskaité, LL.M is a research assistant at the German University of Administrative Sciences Speyer and the German Research Institute for Public Administration. She holds a master's degree in law with specialization on European Union Law from Vilnius University and Europa-Kolleg Hamburg. Currently she is also pursuing a joint PhD at the German University of Administrative Sciences Speyer and at the Vilnius University. Before joining the German University of Administrative Sciences Speyer, she worked in the Supreme Administrative Court of Lithuania 


\section{References:}

Alincai, M. (2012). Le suivi du respect de la soft law au sein du Conseil de l'Europe. SIPE (7), 84-103.

Auby, J. B. \& Dutheil de la Rochère, J. (Eds) (2014). Traité de droit administratif européen. Brussels: Bruylant.

Breuer, M. et al. (Eds) (2013). Der Staat im Recht - Festschrift für Eckart Klein. Berlin: Duncker \& Humblot.

Brever, M. (2017). Impact of the Council of Europe on National Legal Systems, in: Schmahl, S. \& Breuer, M. (Eds) (2017). The Council of Europe. Oxford: Oxford University Press, 802-873.

Bröhmer, J. et al. (Eds) (2005). Internationale Gemeinschaft und Menschenrecht - Festschrift für Georg Ress. Cologne: Carl Heymanns Verlag.

Cannizzaro, E. (2011). Il rilievo di accordi esterni nell'interpretazione degli accordi OMC, in: Ligustro A. \& Sacerdoti G. (Eds) (2011), Problemi e tendenze del diritto internazionale dell'economia. Liber amicorum in onore di Paolo Picone. Naples: Editoriale Scientifica, 513-524.

Chiti, M.P. (2011). Diritto Amministrativo Europeo. Milano: Giuffrè.

Classen, K.D. (2008). Gute Verwaltung im Recht der Europäischen Union. Berlin: Duncker \& Humblot.

Council of Europe (Ed.) (1997). The Administration and You - A Handbook. Strasbourg: Council of Europe Publishing.

Craig, P. (2012). EU Administrative Law. Oxford: Oxford University Press.

Craig, P. \& Hofmann, H. \& Schneider, J.-P. \& Ziller, J. (Eds) (2017). ReNEUAL Model Rules on EU Administrative Procedure. Oxford: Oxford University Press.

Haller, B. et al. (Eds) (2000). Law in Greater Europe. New York: Kluwer Law International.

Harlow, C. \& Leino, P. \& della Cananea, G. (Eds) (2017). Research Handbook on EU Administrative Law. Cheltenham: Edward Elgar.

Hofmann, H. (2008). Mapping the European Administrative Space. West European Politics (31), 662-676.

Hofmann, H. \& Rowe, G.C. \& Türk, A.H. (2011). Administrative Law and Policy of the European Union. Oxford: Oxford University Press.

Huls, N. \& Adams, M. \& Bomhoff, J. A. (Eds) (2008). The Legitimacy of Highest Courts' Rulings. The Hague: T.M.C. Asser Institute.

Hummer, W. \& Wagner, G. (Eds) (1988). Österreich im Europarat 1956-1986: Bilanz einer 30jährigen Mitgliedschaft. Vienna: Verlag der Österreichischen Akademie der Wissenschaften.

Jans, J.H. \& de Lande, R. \& Prechal, S. \& Widdershoven, R.J.G.M (2015). Europeanisation of Public Law. Groningen: Europa Law Publishing.

Keller, H. \& Stone Sweet, A. (2008). A Europe of Rights. The Impact of the ECHR on National Legal Systems. Oxford: Oxford University Press.

Koprić, I. \& Musa, A. \& Lalić Novak, G. (2011). Good Administration as a Ticket to the European Administrative Space. Zbornik Pravnog fakulteta u Zagrebu (61 (5)), 1515-1560.

Le rôle de la volonté dans les actes juridiques - études à la mémoire du professeur Alfred Rieg (2000). Brussels: Bruylant. 
PACE Resolution 1990 (2014) Reconsideration on substantive grounds of the previously ratified credentials of the Russian delegation, 10 April 2014.

PACE Resolution 2034 (2015) on Challenge, on substantive grounds, of the still unratified credentials of the delegation of the Russian Federation, 28 January, 2015.

Palmieri, G.M. (2006). L'internationalisation du droit public: La contribution du Conseil de l'Europe. European Review of Public Law (18), 51-84.

Paužaitè-Kulvinskienè, J. (2000). Der Aufbau der deutschen und litauischen Verwaltungsgerichtsbarkeit. Teise (35), 35-54.

Piličiauskas, R. \& Andrijauskaitè, A. (2014). Teisètų lūkesčių apsaugos principo samprata Lietuvos ir Europos teisinèse sistemose. Practice of Administrative Courts - Bulletin of the Supreme Administrative Court of Lithuania (28), 326-382.

Polakiewicz, J. (2012). Finalités et fonctions de la soft law européenne L'expérience du Conseil d'Europe. SIPE (7), 167-195.

Ramanauskaité, L. (2004). Comparative analysis of Lithuanian administrative procedure. Lituanus 50 (1), 45-53.

Stelkens, U. \& Andrijauskaite, A. (2017). Added Value of the Council of Europe to Administrative Law: The Development of Pan-European General Principles of Good Administration by the Council of Europe and their impact on the administrative law of its Member States. FÖV Discussion Paper No. 86.

Stelkens, U. (2004). Europäische Rechtsakte als 'Fundgruben' für allgemeine Grundsätze des deutschen Verwaltungsverfahrensrechts. Zeitschrift für Europarechtliche Studien (1), 129-163.

Szente, Z. \& Lachmaeyer, K. (Eds) (2017). The Principle of Effective Legal Protection in Administrative Law - A Comparative Perspective in Europe. Abingdon, Oxon; New York, NY: Routledge.

Terhechte, J.P. (Ed.) (2011). Verwaltungsrecht der Europäischen Union. BadenBaden: Nomos.

Trondal, J. \& Guy Peters, B. (2015). A Conceptual Account of the European Administrative Space, in: Baver, M. W. \& Trondal, J. (Eds) (2015). The Palgrave Handbook of the European Administrative System. London: Palgrave Macmillan, 79-92.

von Bogdandy, A. (2017). The Idea of European Public Law Today, in: von Bogdandy, A. \& Huber, P. M. \& Cassese, S. (2017). The Max Planck Handbooks in European Public Law Volume I: The Administrative State, 1-29.

von Danwitz, T. (2008). Europäisches Verwaltungsrecht. Berlin: Springer.

Wakefield, J. (2007). The Right to Good Administration. New York: Kluwer Law International.

Wittinger, M. (2005). Der Europarat: Die Entwicklung seines Rechts und der "europäischen Verfassungswerte". Baden-Baden: Nomos.

Wolfrum, R. \& Röben, R. (Eds) (2005). Developments of International Law in Treaty Making. Berlin: Springer. 


\section{Ustvarjanje dobre uprave s prepričevanjem: Študija primera priporočil Odbora ministrov Sveta Evrope}

Ta članek obravnava manj raziskovano področje upravnega prava, ki izhaja iz Sveta Evrope (CoE), in si prizadeva ugotoviti, ali in kako eden izmed njegovih instrumentov - Priporočila Odbora ministrov Sveta Evrope - vpliva na nacionalne standarde v izbranem pravnem sistemu. $V$ te namene je bila sprva predstavljena ustavna podlaga za ta priporočila in njihove glavne značilnosti. Poleg tega so bila izbrana tista priporočila, ki so pomembnejša za upravno pravo in ki so v središču analize tega dokumenta. Na koncu je bila preučena zaznana pomembnost raznih funkcij, manifestacij in posledic teh priporočil tako, da so bila le-ta postavljena v kontekst, torej da sta bila analizirana njihova uporaba in vpliv na litovsko upravno pravo, s katerim je seznanjen tudi avtor tega dokumenta. Tako se bolj poglobljeno odkrivata potencial priporočil Sveta Evrope in njihov morebitni prispevek k ustvarjanju dobrega upravljanja s prepričevanjem. To prav tako potrjuje splošno zmožnost aktov Sveta Evrope, da vplivajo na nacionalne standarde dobre uprave in pomembnost ohranjanja ter nadaljevanja razprave o njihovem širšem pomenu.

Analiza, opravljena v članku, je razkrila, da v izbranem pravnem redu litovskem nacionalnem pravu - omenjeni instrumenti Sveta Evrope lahko vzbudijo sprejetje sprememb nacionalnih pravnih predpisov, prav tako jih skrbno upošteva tudi sodstvo. Za upravna sodišča so lahko priporočila Sveta Evrope pomemben vir pravnega znanja, ki zmore odražati težnje sodobnega upravnega sodstva. Za ta namen njihova »mehka pravna narava« ne predstavlja ovire. Poleg tega splošnega pomena priporočil, ki ga prepoznajo nacionalni pravni akterji, je študija primera pokazala tudi, da imajo Priporočila Odbora ministrov Sveta Evrope lahko še naslednje (bolj specifične) funkcije: (i) da sklepom ali sodbam dajo večjo pravno moč, še posebej, če upravni spor velja za »kontroverznega« ali ima velik javni interes; (ii) kot pomoč pri boljši razlagi, konkretiziranju in razumevanju raznih norm Evropske konvencije o človekovih pravicah, s čimer se lahko nacionalno sodstvo izogne morebitnim nasprotjem z dolžnostmi, ki jih zajema konvencija; (iii) da vpelje »nove« pravne pojme ali pomaga pri razumevanju nejasnih in je v pomoč upravnim sodiščem, ki so pripravljena reševati upravne spore na bolj konceptualen način; (iv) da reši upravne spore faute de mieux, torej da v situacijah, ko nacionalne norme v določenih primerih ne obstajajo, sodniku prepusti široko diskrecijsko pravico; (v) da spodbuja reforme v primerih, ko je nacionalna zakonodaja zastarela ali normativno omejena.

Pokazalo se je, da so obseg in posledice Priporočil Odbora ministrov Sveta Evrope na nacionalno pravo lahko obsežni, vendar niso brez omejitev. Medtem ko so v »kontroverznih« upravnih zadevah obravnavana, kot da dodajo "pravno težo« reševanju določenega spora in se je nanje lahko zanašati, pa se na določenih področjih, kot je na primer upravno procesno pravo, zdi, da je 
njihovo sprejetje dolgotrajnejše. Tako lahko rečemo, da je dobro upravljanje s prepričevanjem - ki ga sprožijo instrumenti mehkega prava Sveta Evrope - izvedljivo, toda le, dokler so nacionalni pravni akterji pri tem pripravljeni sodelovati. Jasno je, da učinki, ki jih lahko prinesejo ta priporočila, vsekakor niso izčrpni in da so potrebne nadaljnje raziskave. Med drugim bi bilo vredno izvesti primerjalno raziskavo, ki bi preučila, kako Priporočila Odbora ministrov Sveta Evrope prežemajo »mlajše« in »starejše« evropske pravne sisteme in ali med njimi obstajajo večje razlike v sprejetju teh aktov.

Ključne besede: Svet Evrope, evropsko upravno pravo, priporočila Odbora ministrov Sveta Evrope, vseevropska načela dobrega upravljanja, evropski upravni prostor. 